\title{
California's working landscapes offer opportunities for economic growth
}

Glenda Humiston, Vice President, UC ANR

W orking landscapes - croplands, rangelands, timberlands and more - are the basis of economic activity that support millions of Californians. Yet they are often under-appreciated for this economic contribution as well as the vital role they play in providing food, fiber, wildlife habitat, recreational venues, energy and valuable ecosystem services. Our working landscapes represent an un-

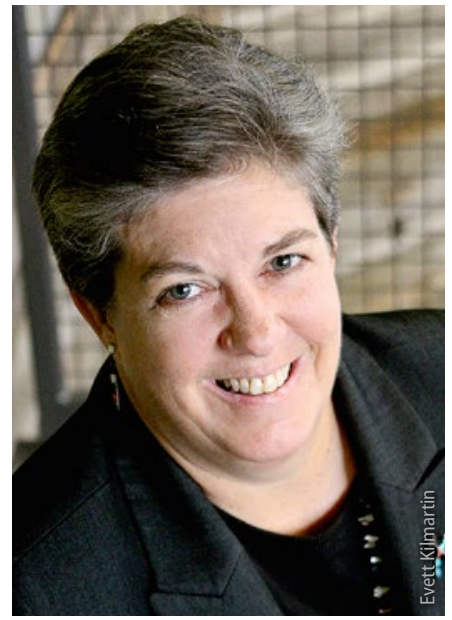
tapped economic potential that must be cultivated.

One goal within the recently adopted UC ANR strategic plan — "Building sustainable economies for working landscapes" - aims to improve that situation for the benefit of our various stakeholders. As goal owner, I will be personally leading an array of partners, along with various ANR personnel, in its implementation.

For over 100 years, UC ANR has been a source of information and expertise that has enabled innovation and economic growth in rural communities. With a presence in every county in the state and a long history as a trusted partner - with private individuals and businesses, schools, community groups, local governments, nongovernmental organizations and state and federal agencies - UC ANR is uniquely positioned to be a catalyst for further economic development throughout California. Toward that goal, we will pursue several actions.

First, we will call attention to our institutional expertise in community economic development and seek out opportunities to leverage existing efforts and broaden our impacts. We'll be emphasizing UC Cooperative Extension (UCCE) programs that already support economic development and looking for new ways to catalyze economic development through the work UC ANR is doing with clients around the state. This represents a long-term prioritization that I believe will yield major benefits.

Second, partnerships. This is one of my big themes, and my work here at UC ANR and previously as the head of USDA Rural Development for California has shown me the power of connections between people, businesses and institutions. Partnerships can open up access to the resources needed to grow a business, create a team to solve a problem, or help to resolve a long-standing conflict. Our research, extension and various programs offer valuable tools that can enhance those efforts. The University Economic Development Association showcases innovations and examples from around the nation that can be adapted for use in California.

Finally, we'll be working to raise awareness of the economic value of working landscapes. At venues like the California Economic Summit, an annual high-level meeting of leaders from around the state, we will carry the message that working landscapes and rural communities can be engines of innovation, job growth and sustainable prosperity.

What does building sustainable economies mean in practice? Economic opportunities can take many forms. What they have in common is using new ideas to meet a need.

For example, one area in which a number of UCCE personnel are working is in the development of what's known as values-based supply chains. Consumers increasingly differentiate among goods - from meat to vegetables to fabric to lumber - produced in a certain location or by a certain set of rules. That sort of differentiating information can have significant market value, but it may be lost in a supply chain that pools products from many sources. A values-based supply chain ensures that the information is passed down to the retail level, enabling producers to capture more value from what they grow or raise and opening up new markets for their goods.

We are also partnering with large-scale economic development organizations like Central Valley AgPLUS, which in 2015 was designated by the U.S. Economic Development Administration as one of 12 Investing in Manufacturing Communities Partnerships in the nation. Central Valley AgPLUS focuses on creating new opportunities in food and beverage processing, with a holistic approach: workforce and training; supplier networks; research and innovation; infrastructure and site development; trade and international investment; and operational improvement and capital access - all areas in which the University of California has resources and knowledge to share.

One of the four aspirations in our mission statement is to help the people of California achieve "economic success in a global economy". The initiatives identified in our new strategic plan will enhance UC ANR's role in developing sustainable economies throughout California and help to build bridges between our urban and rural sectors - a valuable contribution toward a vibrant California! CA 